Spring 2013

\title{
Our Own Private Sustainable Community: Are Green Covenants, Conditions, and Restrictions a Viable Alternative to a More Environmentally Sustainable Future for Homeowners
}

\author{
Darren A. Prum \\ Robert J. Aalberts
}

\section{Recommended Citation}

Darren A. Prum \& Robert J. Aalberts, Our Own Private Sustainable Community: Are Green Covenants, Conditions, and Restrictions a Viable Alternative to a More Environmentally Sustainable Future for Homeowners, 43 N.M. L. Rev. 157 (2013).

Available at: https://digitalrepository.unm.edu/nmlr/vol43/iss1/7 


\title{
OUR OWN PRIVATE SUSTAINABLE COMMUNITY: ARE GREEN COVENANTS, CONDITIONS, AND RESTRICTIONS A VIABLE ALTERNATIVE TO A MORE ENVIRONMENTALLY SUSTAINABLE FUTURE FOR HOMEOWNERS?
}

\author{
By Darren A. Prum* and Robert J. Aalberts**
}

\section{INTRODUCTION}

Residential and commercial property owners have sought for centuries to develop and enrich their physical environments through private land use planning. ${ }^{1}$ In more recent decades, ${ }^{2}$ home owners are residing in Common Interest Communities ${ }^{3}$ ("CICs"). Under this arrangement, homeowners hold title to their residences, as well to the land underlying their homes. A planned development association, often called a Home-

* Assistant Professor Of Legal Studies, The Florida State University. J.D., University of Nevada, Las Vegas, 2002; M.B.A., University of Nevada, Las Vegas, 1997; Graduate Certificate, University of Southern California, 1992; B.S., University of California, Riverside, 1992. Admitted to all New Mexico Courts (State and Federal) and the 10th U.S. Circuit Court of Appeals.

** Ernst Lied Professor Of Legal Studies, University Of Nevada-Las Vegas. J.D., Loyola University, 1982; M.A., University of Missouri-Columbia, 1974; B.A., Bemidji State University, 1972. Admitted to Louisiana State Bar in 1982. Editor-in-Chief, Real Estate Law Journal, 1992 to present.

1. See Robert Kratovil, The Declaration of Restrictions, Easements, Liens, and Covenants: An Overview of an Important Document, 22 J. Marshall L. Rev. 69, 6971 (1988) (discussing why in England during the Industrial Revolution residential homeowners adopted ways to protect their neighborhoods from the encroachments of factories and other sources of nuisance).

2. Indeed since 1970 the estimated number of common interest communities (CICs) has risen from 10,000 in 1970 to 309,600 in 2010 with about 62 million residents inhabiting them. Industry Data: National Statistics, Community Associations InstiTUTE, http://www.caionline.org/info/research/Pages/default.aspx (last visited 04/17/ 2012).

3. CICs, sometimes called Homeowners Associations (HOAs), are comprised of planned single-family developments. See Steven Siegel, A New Paradigm for Common Interest Communities: Reforming Community Associations Through the Adoption of Model Governing Documents that Reject Intricate Rule-Bound Legal Boilerplate in Favor of Clarity, Transparency and Accountability, 40 REAL Est. L.J. 27, 28 n.1 (2011). For discussion of the structure of two other kinds of CICs, condominiums and housing cooperatives, see id. 
owners Association, generally owns and manages the common areas including the parking lots, non-dedicated streets, and various amenities, such as playgrounds and swimming pools. All homeowners become members of the association once they receive title to their properties and must pay fees for the upkeep of the common areas, as well as abide by the rules for maintaining the desired environment declared in the Covenants, Conditions \& Restrictions ("CC\&Rs") that are attached to the deeds." CC\&Rs, which are generally created by the CIC developer, ${ }^{5}$ are mutually binding and enforceable agreements against the people who reside in a CIC. ${ }^{6}$ Importantly, CC\&Rs are monitored under the watchful eye of an empowered planned development association, which is composed of all the homeowners living in the CIC, but enforced by their elected representatives. ${ }^{7}$

4. According to Siegel, "Although CICs may take several different forms, all CICs share the distinguishing characteristic that their establishment and essential authority over constituent homeowners arise from covenants, conditions, and restrictions (commonly known as CC\&Rs) attached to the deeds to the homeowners' real property." Id. at 30 n.9.

5. Id. at 34. More modern CC\&Rs are created by land developers. This has been criticized by various commentators, including Siegel, who contends that functional deficiencies occur because:

[T] he CIC is usually the result of unilateral decisions made by the developer at the planning stage of the development, long before homes are sold and the residents take occupancy. This temporal disjuncture-as between the binding decisions of the political organizer of the community and the affect [sic] of those decisions on the future political constituents of the community-carries significant ramifications with respect to the future governance of the community.

Id. at 34-35. See also, Raymond Hannaman, Homeowners Association Problems and Solutions, 5 Rutgers J.L. \& Pub. PoL'y 699, 704-06 (2008).

6. See generally, Eco-Industrial Strategies: Unleashing Synergy BeTween ECONOMic Development And the Environment 143-44 (Edward CohenRosenthal \& Judy Musnikow eds., Greenleaf Publishing 2003) (discussing the role of CC\&Rs in governing land-use in so-called eco-industrial parks).

7. The powers that community associations possess over a CIC are well documented. Siegel states:

CICs are empowered to issue rules of general applicability affecting residents - as well as nonresidents - within the associations' territorial jurisdiction. For example, CICs typically "exercise extensive land-use powers traditionally associated with the municipal zoning and police-power authority, such as [the] review of proposed home alterations and enforcement of rules governing home occupancy."

Siegel, supra note 3, at 32 (quoting Steven Siegel, The Constitution and Private Government: Toward the Recognition of Constitutional Rights in Private Residential Communities Fifty Years After Marsh v. Alabama, 6 WM. \& MARy Bill RTs. J. 461, 436437.). 
Although the typical post-World War II CC\&Rs were often mundane and only governed topics such as setbacks, parking and vehicular restrictions, architectural requirements, non-household animals, sight and smell nuisances, trash containment, and landscaping and plants, more recent $C C \& R s$ are venturing into uncharted waters; modern $C C \& R s$ are beginning to impose restrictions that promote environmental sustainability. More specifically, a growing number of CICs are establishing green building provisions, such as those certified by the United States Green Building Council (USGBC), which maintains its now-familiar Leadership in Energy and Environmental Design, or LEED, rating system. ${ }^{8}$ Initial attempts at promoting environmental sustainability ratings have placed an emphasis on improved water usage and environmentally compatible landscaping, ${ }^{9}$ but the green movement is now expanding in ever-greater directions, including architectural design. This article will discuss the various tools being used to promote sustainable communities through private means, and it offers a practical and sound approach for developers seeking to achieve such goals within a given project.

In Part II of this article, we present a brief history of private land use arrangements and their present-day applications. These arrangements include defeasible fees, negative easements, and deed restrictions. In particular, we discuss how deed restrictions, real covenants, and equitable servitudes are formed, in addition to their limitations and how they fit into a world with rapidly changing technology and environmental awareness. Part II will also discuss the crucial role of the CC\&Rs' architectural

8. Charles J. Kibert, Sustainable Construction: Green Building DeSIGN AND DELIVERy 47-49 (2d ed. 2007). The USGBC's LEED program is designed as a collection of building rating systems that offers certification for many different types of construction like existing building operations, commercial interiors, core and shell projects, homes, and neighborhood developments. Id. at 55-62. Directed by the LEED program type, a governing committee establishes requisites for certification that allocates points into categories recognized by the group as a sustainable practice. See LEED Committees, U.S. Green BuIlding CouncIL, http://www.usgbc.org/DisplayPage.aspx?CMSPageID=1750 (last visited Apr. 13, 2012). The committee creates thresholds for recognizing the project based on the points achieved, which begins at a basic certification level and then proceeds to Silver, Gold, and Platinum. GreEN Building Certification Institute, LeEd Certification Policy Manual 6 (2011).

9. See, e.g., Nancy Kubasek, The Conflict Between Homeowners' Associations and the Environment, 33 REAL Est. L. J. 203 (2004) (discussing the conflicts arising between CICs and residents over the installation of environmentally friendly features such as artificial turf). See also Edna Sussman, Reshaping Municipal and County Laws to Foster Green Building, Energy Efficiency, and Renewable Energy, 16 N.Y.U. ENVTL. L.J. 1 (2008) (discussing private covenants as well as public policy initiatives for promoting environmental sustainability). 
review board, which must approve building requirements and changes, including those changes involving green buildings. In Part III, we begin by discussing traditional green applications used in residential CC\&Rs. This discussion is followed by a presentation of the very new but growing number of CICs, in which the purpose is to create a more sustainable environment through the attainment of a green rating. Two of these new green CICs in Maine and Oregon, which we present as case studies, will illustrate how these goals are being pursued and their probable success. In Part IV, we offer insights and suggestions on the ways in which various communities may build a more sustainable and green environment for the future.

\section{PRIVATE LAND USE RESTRICTIONS: A BRIEF HISTORY AND PRESENT DAY APPLICATIONS}

Under the common law, property owners employ various legal devices to privately order and allocate land use. These traditional devices include defeasible fees, negative easements, real covenants, and equitable servitudes. Although of recent invention, we also present in Part II a discussion of the role of Architectural Review Boards, which must interpret the CC\&Rs and thus functionally affect private land use.

\section{A. Defeasible Fees}

Defeasible fees are present estates that can potentially last in perpetuity like a fee simple absolute. They differ, however, by terminating once a specified, but usually not certain, event occurs as provided in an instrument such as a will or deed..$^{10}$ There are three kinds of defeasible fees, namely the fee simple determinable ${ }^{11}$ fee simple subject to a condition subsequent, ${ }^{12}$ and fee simple subject to an executory limitation, ${ }^{13}$ which have been employed for regulating the disposition and use of real

10. Roger A. Cunningham et al., The Law of Property 35 (2d ed. 1993).

11. Id. at 39 .

12. Id. at 42. An example of a fee simple subject to a condition subsequent is "to A and his heirs upon the express condition [provided, however,] that the land hereby conveyed shall be used for no other purpose than as a burying ground." Id. The grantor's future estate is the right to re-enter or terminate the estate and requires an "actual entry on the land after breach of the condition, in the presence of witnesses, in order to terminate the fee simple." $I d$. at 44.

13. The fee simple subject to an executory limitation is defined as "a fee simple estate which, upon the happening of a designated event, will automatically pass to a designated person other than the person who created the defeasible estate or his (or her) successor in interest." $I d$. at 54. The executory interest is the future estate associated with this defeasible fee. Id. at 54-55. 
property for centuries. ${ }^{14}$ These tools now continue to be applied as they were first used in England and the United States, as well as in more modified forms today. ${ }^{15}$ To illustrate, in a fee simple determinable, O, the owner of Blackacre, is allowed to restrict future use of his estate by declaring in his deed or will the following words of limitation "to A and his heirs so long as the land is used for agricultural purposes." 16 In that case, $\mathrm{A}$ and his heirs would be bound by the land use restrictions imposed by $\mathrm{O}$ on Blackacre. If $\mathrm{A}$ and his heirs attempt to subdivide and build houses, $\mathrm{O}$ and his heirs, who possess a future estate called a "possibility of reverter," would automatically regain title in fee simple absolute. ${ }^{17}$

Both the fee simple determinable and the fee simple subject to a condition subsequent are generally limited to non-commercial land uses conferred to "charitable, educational, or other eleemosynary institutions." 18 The fee simple subject to an executory limitation is employed

14. Id. "Estates in fee simple subject to a qualifying limitation that the estate shall last only 'so long as' a designated state of affairs shall continue or only 'until' the occurrence of a designated event were recognized as permissible estates at an early date in England." Id. at 39.

15. Id. "Such qualified fee simple estates may still be created under modern English and American law." Id. It should be noted, however, that some American jurisdictions have modified and even abolished defeasible fees by court decision or statute. See, e.g., Ky. Rev. Stat. Ann. § 381.218 (2006). "The estate known at common law as the fee simple determinable and the interest known as the possibility of reverter are abolished. Words which at common law would create a fee simple determinable shall be construed to create a fee simple subject to a right of entry for condition broken. In any case where a person would have a possibility of reverter at common law, he shall have a right of entry." Id.

16. See Cunningham, supra note 10 , at 39 .

17. A possibility of reverter is a future estate owned by the grantor and created "[w] hen the residue of the fee simple absolute is retained by the person creating the fee simple determinable (or his heirs), he is said to retain a possibility of reverter." Cunningham, supra note 10, at 40.

18. See generally Cunningham, supra note 10 , at 42,45 . See also White v. Metropolitan Dade County, 563 So.2d 117 (Fla. Dist. Ct. App. 1990) (expressing conveyance in 1940 deed: "This conveyance is made upon the express condition that the lands hereby conveyed shall be perpetually used and maintained for public park purposes only; and in case the use of said land for park purposes shall be abandoned, then and in that even the said [grantor], his heirs, grantee or assigns, shall be entitled upon their request to have the said land reconveyed to them."). Id. at 121. In 1986 the Dade County Commissioners contracted for an international tennis tournament to be played in the park for two weeks each year. Grantor's heirs sued to enjoin the tournament and the court granted the injunction ruling that the tennis tournament violated the deed restrictions. Id. at 132. Defeasible fees have also been displaced by the use of trusts which are more flexible and have the advantage of being overseen by a trustee, who is personally liable as a fiduciary, and a trust instrument which can offer specific 
primarily to create beneficial interests in trusts and is more associated with "personal property such as stocks and bonds." 19

Defeasible fees are typically written in general terms to restrict the use of property, such as prohibitions against commercially developing agricultural land, limiting land conveyed to a charitable organization for only non-profit uses, or dictating that a property shall be left in a pristine state. ${ }^{20}$ Thus, it would almost certainly be a clumsy and ineffective tool to use for the design of environmentally restrictive building codes that govern the actions of property owners in an environmentally sustainable residential development. These developments demand very specific and comprehensive rules and procedures for navigating through an uncertain future. ${ }^{21}$ Moreover, defeasible fees impose a general restriction that usually does not have to be actively monitored, while an environmentally sustainable community's inherent complexity would require its rules be closely supervised and enforced through its planned development association. ${ }^{22}$

\section{B. Negative Easements}

Negative easements burden property owners in the manner in which the owners can or cannot use their land for the benefit of appurtenant property owners. ${ }^{23}$ Thus, the owner of a negative easement can literally prevent the burdened landowner from performing certain acts on his own property. Often used and typically referred to as an "easement of light, air, and view," 24 a negative easement might encompass an agreement between $\mathrm{O}$, owner of a burdened or servient property, and A, possessor of the appurtenant dominant tenement, providing that $\mathrm{O}$ not be allowed to

terms and instructions on how land is used. See also, Robert J. Aalberts, Real Estate LAW 144 (8th ed. 2012).

19. Cunningham ET AL., supra note 10 , at 58.

20. See supra note 18 for discussion of cases using defeasible fees. See also, AALBERTs, supra note 18, at 137-39.

21. But see Gerald Korngold, For Unifying Servitudes And Defeasible Fees: Property Law's Functional Equivalents, 66 TEx. L. REV. 533 (1988) (making the case that defeasible fees and servitudes are essentially equivalent even though they are often distinguished in legal theory and as such could be used to resolve legal disputes involving forfeiture remedy, ownership in gross, permissible subject matter, and termination and modification doctrines. Korngold also acknowledges the differences between real covenants, which are consensual, and defeasible fees, which are granted).

22. See infra text accompanying notes 124-149 for discussion of the intricacies and potential legal pitfalls the authors contend are inherent in environmentally restrictive building codes.

23. Cunningham ET AL., supra note 10 , at 440.

24. Id. 
build more than one story on his property in order to allow air and light to enter onto A's parcel. ${ }^{25}$ Successors to either O or A, such as buyers, heirs, and legatees, would likewise be bound by the prohibition. Any violation by $\mathrm{O}$ can be enforced by $\mathrm{A}$ with a remedy in damages, as well as in equity, such as an injunction to cease the prohibited construction. ${ }^{26}$

An ongoing controversy involving negative easements concerns whether the beneficiaries of light, air, and view can, after the fact, prohibit an appurtenant property owner from blocking access to the light, air, and view. Most states have ruled the owner of the dominant tenement does not have a right to limit his neighbor's land use as the servient tenement. ${ }^{27}$ Few courts have ruled that such an obstruction can constitute a common-law nuisance. ${ }^{28}$ In an important development, a growing number

25. Susan F. French, Toward a Modern Law of Servitudes: Reweaving the Ancient Strands, 55 S. CAL. L. REV. 1261, 1266-67 (1982). While often created by adjoining or appurtenant estates or tenements, negative easements in the United States are generally allowed to be made in favor of a person or "in gross" as well. Unless commercial in nature, easements in gross are generally not assignable or inheritable because they are personal, while easements appurtenant are real rights which attach and run with the land. $I d$. at 1268 .

26. Id. at 1269 .

27. Aalberts, supra note 18, at 97-8. See also Fontainbleau Hotel Corp. v. FortyFive Twenty Five, Inc., 114 So. 2d 357 (Fla. Dist. Ct. App. 1959):

No American decision has been cited, and independent research has revealed none, in which it has been held that-in the absence of some contractual or statutory obligation - a landowner has a legal right to the free flow of light and air across the adjoining land of his neighbor. Even at common law, the landowner had no legal right, in the absence of an easement or uninterrupted use and enjoyment for a period of 20 years, to unobstructed light and air from the adjoining land. (citations omitted) And the English doctrine of "ancient lights" has been unanimously repudiated in this country.

Id. at 359. Similarly, in Hefazi v. Stiglitz, 862 A.2d 901, 911 (D.C. 2004), a court ruled that easement rights to air and light cannot be created impliedly by prior use. See generally Sara C. Bronin, Solar Rights, 89 B.U. L. REv. 1217 (2009) (discussing public and private laws for creating solar rights).

28. See Prah v. Maretti, 108 Wis.2d 223, 321 N.W.2d 182 (Wis. 1982):

Private nuisance law, the law traditionally used to adjudicate conflicts between private landowners, has the flexibility to protect both a landowner's right of access to sunlight and another landowner's right to develop land. Private nuisance law is better suited to regulate access to sunlight in modern society and is more in harmony with legislative policy and the prior decisions of this court than is an inflexible doctrine of non-recognition of any interest in access to sunlight across adjoining land.

We therefore hold that private nuisance law, that is, the reasonable use doctrine as set forth in the Restatement, is applicable to the instant case. Recognition of a nuisance claim for unreasonable obstruction of access to sunlight will not prevent land development or unduly hinder the use of adjoining land. It will promote the reasonable use and enjoyment of land in a manner suitable to the 1980's. That obstruction of access to light might be found to constitute a 
of jurisdictions have enacted statutes granting continuing access to the sun to a property owner who has solar-collection equipment, in effect creating a negative easement on the adjacent property owner, who could potentially block such access. ${ }^{29}$ These new cases and statutes are helpful for promoting a limited kind of green development, in this case solar collectors on burdened landowners. But this would likely be an ineffective method for creating a comprehensive sustainable residential environment governed by an extensive array of CC\&Rs imposing reciprocal burdens and benefits on property owners, and it would require close monitoring and enforcement. ${ }^{30}$

A potentially "green" species of negative easements of more recent vintage is the conservation easement. ${ }^{31}$ These easements are used, for example, "to limit uses and development of a property that would be inconsistent with its agricultural, scenic, natural, or open character." 32 Thus, conservation easements are created more to conserve land in its present

nuisance in certain circumstances does not mean that it will be or must be found to constitute a nuisance under all circumstances. The result in each case depends on whether the conduct complained of is unreasonable.

Id. at 191 .

29. Aalberts, supra note 18, at 97-98. See, e.g., NMSA 1978, § 47-3-8 (1983).

New Mexico's statute specifically provides:

A solar right may be claimed by an owner of real property upon which a solar collector has been placed. Once vested, the right shall be enforceable against any person who constructs or plans to construct any structure, in violation of the term of the Solar Rights Act or the Solar Recordation Act. A Solar right shall be considered an easement appurtenant, and suit to enforce a solar right may be brought at law or equity.

Id. In regards to obstructing solar access a few jurisdictions have created an implied easement by necessity while other jurisdictions have enjoined the obstructing party under an analogy to the state's spite fence law if the obstruction is done purposefully and with malice. See Jay M. Zitter, Annotation, Solar Energy: Landowner's Rights Against Interference With Sunlight Desired for Purposes of Solar Energy, 29 A.L.R. 4th 349, 351 (1984).

30. CUnNingham ET AL., supra note 10, makes the additional point that negative easements, as compared to deed restrictions contained in CC\&R's and used in environmentally sustainable developments, are interpreted differently by courts. The language creating negative easements are historically given narrow application while covenants are interpreted liberally. $I d$. at 467 . This means, according to the authors, a better outcome for homeowners who "regard a tight system of restrictive covenants as desirable; they are willing to pay more for homes protected (and restricted) by such covenants than for homes not so protected." Id.

31. See Nancy A. McLaughlin, Conservation Easements-A Troubled Adolescence, 26 J. Land Resources \& Envtl. L. 47 (2005). According to Nancy A. McLaughlin, "[Although] the modern concept of a 'conservation easement' was first introduced by journalist William Whyte in the late 1950s, it was not until the mid-1980s that conservation easements began to be used on a widespread basis." Id. at 49.

32. Aalberts, supra note 18 , at 98. 
state, rather than dictate how property owners structure and use their property. As such, they too would be unworkable for solving the kinds of complex land use issues confronting residential developments, including green buildings.

\section{Real Covenants}

Real covenants, along with their closely related cousin, equitable servitudes, generally offer the primary legal means today for creating comprehensive residential and commercial developments. ${ }^{33}$ Real covenants, similar to defeasible estates and negative easements, also date back to the early common law. ${ }^{34}$ The essential feature of a real covenant is its ability of "'running' to persons who subsequently have certain connections with the same land or lands with which the covenantor or convenantee, or both, were connected." ${ }^{35}$ Under these connections, property owners fashion mutually enforceable promises ${ }^{36}$ in which an owner refrains from doing something on his own property but is benefitted because all the other similarly situated owners are refraining from doing the same thing to their lands. ${ }^{37}$ Real covenants today are most generally used

33. See supra text accompanying notes $2-7$ and infra $65-81$ discussing equitable servitudes and how they relate to real covenants.

34. Spencer's Case, (1583) 77 Eng. Rep. 72, 5 Co. 16a (Q.B.). In Spencer's Case a lessee had covenanted to build a new wall. $I d$. The court ruled that the burdens were also binding on his assignees so long as they touched or concerned the land. Id. at 74 . For a more thorough discussion of Spencer's Case, see Edwin A. Abbot, Jr., Covenants in a Lease Which Run With the Land, 31 YALE L. J. 127 (1921).

35. Cunningham et AL., supra note 10, at 466.

36. The ability of real covenants and equitable servitudes to be easily discovered both in fact as well as constructively is made possible by statutory and non-statutory declarations of restrictions recorded contemporaneously with a plat map. The deed references the plat while the plat contains a statement that the land in the subdivision is restricted by what is provided in the CC\&Rs. This process, as noted by real estate commentator Robert Kratovil, protects titles:

The rule is that if a recorded document makes reference to another recorded document, the two will be read together. Note also that the declaration itself is in the chain of title. When the plat is recorded, no lots have been conveyed. Therefore, the name of the developer who signed the plat and the declaration must be searched by prospective purchasers. Hence, the attorney searching the site can be certain that any recorded declarations will be found if it has been properly recorded.

Kratovil, supra note 1 , at 70-71.

37. There is a noteworthy relationship between contract and property law with regard to real covenants. Contracts generally allow the original parties in privity to assign their rights and delegate their duties. With real covenants, however, express assignment or delegation does not happen; rather more remote persons acquire an interest in land of which attaches both burdens and benefits. See Cunningham ET AL., supra note 10, at 468 . 
in residential developments and are sometimes referred to as "reciprocal subdivision covenants." 38 Under this arrangement, subdivision lots are uniformly burdened and benefitted and are generally interpreted liberally to promote the collective goals of the community. ${ }^{39}$

According to author Roger Cunningham, there are five requirements for creating real covenants running with the land. ${ }^{40}$ They are: "(1) the form of the covenant; ${ }^{41}(2)$ whether the covenanting parties intended the covenant to run; ${ }^{42}(3)$ whether the covenant touches and concerns, ${ }^{43}$ (4) whether there is privity between one or both of the covenanting parties and the remote party or parties sought to be benefited or burdened (called 'vertical privity'), ${ }^{44}$ and (5) whether there is privity between the original covenanting parties (called 'horizontal privity')." ${ }^{4}$

38. Id. at 467. See also Siegel, supra note 3 and discussion in text accompanying supra notes 2-3.

39. Cunningham et Al., supra note 10, at 467.

40. Cunningham, supra note 10, at 469 (referencing Charles E. Clark, Real Covenants and Other Interests Which "Run with the Land" 94 (2d ed. 1947)).

41. "In deciding whether the real property Statute of Frauds applies to the creation of running covenants, the Restatement of Property and most writers on the subject agree that running covenants, as proprietary interests in land, must be created in conformity with the Statute of Frauds." Id. at 470.

42. "Intent is to be found from all the circumstances surrounding the covenant. Obviously the use of the word 'assigns' is highly persuasive of an intent to bind successors." Id. at 475 .

43. "The clearest example of a covenant that meets the requirement [of touch and concern of the land] is one calling for the doing of a physical thing to land." $I d$. at 471. However, any requirement that the restriction in question must touch and concern the land in a physical sense "has long since been abandoned in America." Id.

44. With vertical privity,

. . . the burden passes with a transfer of the estate the covenantor held in the burdened land; and the benefit passes with a transfer of the estate, or at least some lesser estate carved out of the estate, that the covenantee held in the benefited land. It is, therefore, more precise to say that the respective estates, and not 'lands,' are benefited and burdened. As the quaint phrase puts it, real covenants run along with estates as a bird rides on a wagon.

Id. at 476 (citation omitted). It should also be noted that, while not actually in privity, CICs are "expressly designated as having power to enforce the covenant acts as agent for the benefited landowners." Cunningham, supra note 10, at 477.

45. Horizontal privity is the "relationship between the original parties, covenantor and covenantee ..." Id. at 477. The courts and commentators are split on the issue of horizontal privity with some requiring it for the burden side to run with the land as well as on the benefit side. As Roger A. Cunningham notes, "The issue [of horizontal privity] will probably die before it is resolved, because the courts now rely heavily upon theories of equitable restrictions and little upon real covenant doctrine." Id. at 480 . 
An impressive volume of literature ${ }^{46}$ and case law ${ }^{47}$ has evolved discussing and analyzing the often arcane subject of real covenants. ${ }^{48}$ How-

46. See id. at 469-84. The legal literature is rich with articles on the subject of easements, real covenants and equitable servitudes, which one commentator contends is the "most complex and archaic body of American property law remaining in the twentieth century." Susan P. French, Toward a Modern Law of Servitudes: Reweaving the Ancient Strands, 55 S. Cal. L. Rev. 1261, 1261 (1982).

47. See Cunningham., supra note 10, at 466-84.

48. Charles E. Clark, Real Covenants And Other Interests Which "Run With Land" (2d ed. 1947); Henry H. Sims, A Treatise On Covenants Which Run With Land Other Than Covenants For Title (1901); Edwin H. Abbot, Jr., Covenants in a Lease Which Run With the Land, 31 YALE L.J. 127 (19211922); Covenants in a Lease Which Run With the Land, 31 YALE L.J. 127 (1921-1922); Ralph W. Aigler, The Running With the Land of Agreements to Pay For a Portion of the Cost of Party-Walls, 10 Mich.L.Rev. 187 (1911-1912); Lawrence Berger, A Policy Analysis of Promises Respecting the Use of Land, 55 MinN. L. Rev. 167 (1970-1971); Kenneth J. Bialkin \& Willis W. Bohannan, Covenants Not to Establish a Competing Business_Does the Benefit Pass?, 41 VA. L. Rev. 675 (1955); Harry A. Bigelow, The Content of Covenants in Leases, 12 Mich.L.Rev. 639 (1913-1914); Albert S. Bolles, Covenants and Estates in Land in Law \& Equity, 33 Dick.L.Rev. 50 (Oct. 1928-May 1929); Percy Bordwell, English Property Reform and Its American Aspects, 37 YALE L.J. 1, 18 (1927); Olin L. Browder, Running Covenants and Public Policy, 77 Мich. L. Rev. 12 (1978-1979); Alfred F. Conard, Easement Novelties, 30 CAlif. L.Rev. 125 (1942); Allison Dunham, Promises Respecting the Use of Land, 8 J.L. \& Econ. 133 (1965); Robert C. Ellickson, Alternatives to Zoning: Covenants, Nuisance Rules, and Fines as Land Use Controls, 40 U. ChI. L. Rev. 681 (1973); Paula A. Franzese, "Out Of Touch:" The Diminished Viability of the Touch and Concern Requirement in the Law of Servitudes, 21 Seton Hall L. Rev. 235, 257 (1990-1991); Susan F. French, Can Covenants Not to Sue, Covenants Against Competition and Spite Covenants Run with Land? Comparing Results Under the Touch or Concern Doctrine and the Restatement Third, Property (Servitudes), 38 Real Prop. Prob. \& Tr. J. 267 (2003-2004); Wayne S. Hyatt, Common Interest Communities: Evolution and Reinvention, $31 \mathrm{~J}$. Marshall L. Rev. 303 (1997-1998); Jan Z. Krasnowiecki, Townhouses with Homes Associations: A New Perspective, 123 U. PA. L. Rev. 711 (1975); Robert Kratovil, Building Restrictions-Contracts or Servitudes, 11 J. Marshall J. Prac. \& Proc. 465 (1977-1978); Julia D. Mahoney, Perpetual Restrictions on Land and the Problem of the Future, 88 VA. L. Rev. 739 (2002); Julia D. Mahoney, The Illusion of Perpetuity and the Preservation of Privately Owned Lands, 44 Nat. Resources J. 573 (2004); Paul McCarthy, The Enforcement of Restrictive Covenants in France and Belgium: Judicial Discretion and Urban Planning, 73 Colum. L. Rev. 1 (1973); Ralph A. Newman \& Frank R. Losey, Covenants Running with the Land, and Equitable Servitudes; Two Concepts, or One?, 21 Hastings L.J. 1319 (1969-1970); Uriel Reichman, Judicial Supervision of Servitudes, 7 J. Legal Stud. 139 (1978); Uriel Reichman, Residential Private Governments: An Introductory Survey, 43 U. CHI. L. Rev. 253 (1975-1976 English Property Reform and Its American Aspects, 37 Y ALE L.J. 1, 18 (1927); Alfred F. Conard, Easement Novelties, 30 Calif. L.Rev. 125 (1942); Russell R. Reno, The Enforcement of Equitable Servitudes in Land: Part I, 28 VA.L.Rev. 951 (1941-1942); Charles B. Sheppard, Land Use Covenants: A Summary of Aspects of California Law 
ever, our intent is not to focus on how real covenants are generally structured. Indeed, modern residential developments are presently governed by broadly accepted, boilerplate CC\&Rs that have incorporated well-settled requirements for real covenants and equitable servitudes. ${ }^{49}$ As a consequence, most disputes surrounding CC\&Rs concern the nature of the restrictions ${ }^{50}$ and how the governing bodies enforce them against the actions of property owners who may violate them. ${ }^{51}$ As such, our dis-

Regarding Land Use Covenants with Comparisons To The Restatement (Third) Of Property, 37 W. ST. U. L. Rev. 27 (2009-2010); Henry Upson Sims, The Law of Real Covenants: Exceptions to the Restatement of the Subject by the American Law Institute, 30 Cornell L.Q. 1 (1944); Jeffrey E. Stake, Toward an Economic Understanding of Touch and Concern, 1988 Duke L.J. 925 (1988); William B. Stoebuck, Running Covenants: An Analytical Primer, 52 Wash. L. Rev. 861 (1976-1977); Harlan F. Stone, The Equitable Rights and Liabilities of Strangers to a Contract, 18 Colum. L.Rev. 291 (1918); William F. Walsh, Covenants Running With the Land, 21 N.Y.U. L. Q. 28 (1946); Townhouses with Homes Associations: A New Perspective, 123 U. PA. L. ReV. 711 (1975); Margot Rau, Note, Covenants Running With the Land: Viable Doctrine or Common-Law Relic?, 7 Hofstra L. Rev. 139 (1978-1979).

49. See Siegel, supra note 3, at 36 n.37 ("In general, developer-imposed CIC templates are remarkably uniform.”). Moreover, according to Siegel, CC\&Rs are categorically written private laws meant to create a "command and control" rule regime designed to protect the interests of the developer, the lender and their attorneys. Id. at 36 .

50. Recent controversies surrounding residential CC\&Rs include whether they are legal when used to discriminate against housing inhabited by the mentally and physically challenged. E.g., Hill v. Community of Damien of Molokai, 1996-NMSC008, 121 N.M. 353, 911 P.2d 861 (holding that restrictive covenants which provided for only single family residences in the community could not be used to keep out four, unrelated persons with AIDS. It was invalid since the term "family" was not defined and CC\&Rs should be construed in favor of the free enjoyment of the land. Moreover, public policy favors allowing living arrangements for the disabled). Other recent controversies involve free speech and expression and enforcement issues such as "super liens" granting associations a priority under law over first mortgages, and protection under so-called "Homeowners' Bill of Rights" from overzealous CC\&R enforcement, AAlBerts, supra note 18, at 531-32; as well as ongoing issues with commercial restrictions, particularly restricting what kinds of products can be sold under restrictive covenants. See, e.g., Dan's Super Market, Inc. v. Wal-Mart, 38 F.2d 1003 (8th Cir. 1994) (ruling that Wal-Mart could sell food and grocery items because the covenants it was bound by were ambiguous and therefore should be strictly construed against the party seeking to enforce them). Other issues with commercial enterprises involve "a store's size, color, design, signage, and setback requirements within [a] mall, as well as any obnoxious or undesirable uses that other tenants and the landlord may find objectionable." AALBERTs, supra note 18, at 533. See generally Marc E. Rosendorf \& Jill Reynolds Seidman, Restrictive Covenants-The Life Cycle of a Shopping Center, РRов \& Prop. 33 (1998).

51. For example, Siegel, supra note 3 , at 34 notes that "[t]he typical CIC regime has been widely criticized as a legal straightjacket of rules that can lead to confusion, 
cussion in Parts III and IV will assume that the green covenants are legally constituted while we concentrate on their potential importance and applications.

One issue that requires attention and may have a potentially important application to the future viability of green residential developments is the means in which real covenants are terminated. Termination may be a critical issue for several possible reasons. For example, if the association fails to impose its CC\&Rs upon a violator, their right of action may be barred by a state's statute of limitations. ${ }^{52}$ Similarly, if the association is dilatory in pursuing a purported violator, the defense of laches may cut off its right to enforce them..$^{53}$ Moreover, a change in neighborhood could possibly destroy the enforceability of these kinds of developments. ${ }^{54}$

The most obvious mode of termination is by express language, such as when the instrument creating the interest expressly provides that the covenants will expire in twenty-five years. ${ }^{55}$ Similarly, the benefiting parties may choose to release their interests. ${ }^{56}$

Additionally, statutes in some states provide a limit on how many years a real covenant and similar burdens can exist. For example, in Massachusetts, there is a prescribed limitation of thirty years for real covenants. ${ }^{57}$ Real covenants can also be terminated if the defendant raises the statute of limitations in a timely manner. This can arise, as demonstrated in California, when an allegedly aggrieved party fails to raise a violation of the real covenant within five years. ${ }^{58}$ Although not as widespread, real

misunderstanding, discontent, inefficiency and abridgement of the personal autonomy of CIC homeowners." Siegel further blames the problems primarily on the fact that the CC\&Rs are created by developers "with only minimal regulatory oversight." Id.

52. See infra text accompanying note 58 .

53. See discussion infra note 81 .

54. See infra text accompanying note 58 .

55. Cunningham, supra note 10 , at 481.

56. Id.

57. Mass Gen. Laws ch. 184, § 23 (2007) provides:

Conditions or restrictions, unlimited as to time, by which the title or use of real property is affected, shall be limited to the term of thirty years after the date of the deed or other instrument or the date of the probate of the will creating them, except in cases of gifts or devises for public, charitable or religious purposes.

See also, Patterson v. Paul, 863 N.E.2d 527 (Mass. 2007) (discussing the termination of negative easements, equitable servitudes and real covenants running with the land after thirty years).

58. Cal. Civ. Proc. Code $\S 336$ (West 2011). Within five years:

(a) An action for mesne profits of real property.

(b) An action for violation of a restriction, as defined in Section 784 of the Civil Code. The period prescribed in this subdivision runs from the time the person seeking to enforce the restriction discovered or, through the exercise 
covenants can also be terminated by at least four more ways: adverse possession, destruction of the servient tenement, foreclosure of a lien superior to the covenant, and eminent domain. ${ }^{59}$

Quite possibly the thorniest means of terminating real covenants occurs under the "change of neighborhood" doctrine. This doctrine is invoked when "change has caused the restriction to become outmoded and to have lost its usefulness, so that its benefits have already been substantially lost." ${ }^{60}$ The manner in which this doctrine can terminate real covenants is complicated and subject to ongoing debates. According to Cunningham et al., the most common theory, accepted by a number of states and by the Restatement,${ }^{61}$ is that the change of neighborhood doctrine constitutes an equitable defense against a party seeking to enforce the burdening of another party under the covenant. ${ }^{62}$ In such a case, the enforcing party could be enjoined from enforcement but could not sue for legal damages even if the injunction was granted. ${ }^{63}$ Because of this substantively deficient outcome, a number of commentators have challenged the theory. ${ }^{64}$

\begin{abstract}
of reasonable diligence, should have discovered the violation. A failure to commence an action for violation of a restriction within the period prescribed in this subdivision does not waive the right to commence an action for any other violation of the restriction and does not, in itself, create an implication that the restriction is abandoned, obsolete, or otherwise unenforceable. This subdivision shall not bar commencement of an action for violation of a restriction before January 1, 2001, and until January 1, 2001, any other applicable statutory or common law limitation shall continue to apply to that action.
\end{abstract}

$I d$. In addition, “'[r]estriction,' when used in a statute that incorporates this section by reference, means a limitation on, or provision affecting, the use of real property in a deed, declaration, or other instrument, whether in the form of a covenant, equitable servitude, condition subsequent, negative easement, or other form of restriction." Cal. Civ. Code $§ 784$ (West 2009).

59. Sheppard, supra note 48, at 61-64.

60. Cunningham et Al., supra note 10, at 482.

61. Restatement (First) of Prop.: Change of Conditions $§ 564$ (1944): Injunctive relief against violation of the obligations arising out of a promise respecting the use of land cannot be secured if conditions have so changed since the making of the promise as to make it impossible longer to secure in a substantial degree the benefits intended to be secured by the performance of the promise.

Id.

62. See generally id.; This defense is part of a "balancing the equities" to achieve a balance between the letter of the law and creating justice. CUNNINGHAM ET AL., supra note 10 , at 483 .

63. See Cunningham et Al., supra note 10, at 483.

64. Id. One commentator, Harry M. Cross, argues that the change of neighborhood doctrine is an equitable action that is transformed into a defense under the law. Id. The court in Roger A. Cunningham et al. asserts that this still leaves open the fact that not all equitable defenses can be transformed and that the issue of whether the 


\section{Equitable Servitudes}

While the distinction is more theoretical than practical, today's deed restrictions are, in fact, enforceable under equitable principles and are commonly referred to as equitable servitudes. Indeed, "[equitable servitudes] have nearly replaced real covenants in the courts today. Recent court decisions rarely turn upon real covenant doctrine." ${ }^{65}$

Equitable servitudes are also of more recent vintage than real covenants, having first been recognized in the 1848 case of Tulk v. Moxey. ${ }^{66}$ The elements for creating an equitable servitude are very similar to that of real covenants. For example, while there has been an ongoing debate historically over whether equitable servitudes are governed by the statute of frauds, the majority of courts have held that it is an interest in land and therefore is subject to the statute's requirements. ${ }^{67}$ Moreover, equitable servitudes generally apply both the touch and concern element ${ }^{68}$ and vertical privity element. ${ }^{69}$

interest still exists is not resolved since the transformation only bars the remedies. Id. Another commentator, Roscoe Pound, maintains that, as with easements, the restriction ends when its purpose ends - an outcome that can be logically inferred by the actions of the restriction's creator. $I d$.

65. Id. at 486. Equitable servitude theory may not be applied in two situations, "when they [plaintiffs] seek money damages, which equity ordinarily will not grant; and, in perhaps a few jurisdictions, where courts will not enforce affirmative covenants in equity." Id. "In recent years, there has been a trend to extend the "changed conditions' doctrine from equitable servitudes to real covenants, so that in some jurisdictions it is now possible to obtain judicial release from the obsolete covenants." French, supra note 25, at 1275-76.

66. Kratovil, supra note 1 , at 70 . Kratvoil has argued that the creation of equitable servitudes arose in the mid-19th century for good reason. "This was the very heart of the Industrial Revolution [1848], which was triggered by the invention of the steam engine late in the eighteenth century. Coal-fired factories were springing up all over England and some device was needed to protect residential areas from invasion by factories." Id.

67. Cunningham ET AL., supra note 10, at 487.

68. French, supra note 25, at 1277 ("Similarly, courts have taken the touch and concern and vertical private requirements from the law covenants and applied them to equitable servitudes.").

69. See supra text accompanying note 44 . Vertical privity differs between law and equity. To illustrate, real covenants run with estates in land or as the simile goes "like a bird in a wagon." See French, supra note 25, at 1264-65 n.16. With equity, however, the equitable restrictions "sink their roots into the soil." See CunNingham ET AL., supra note 10, at 491. The practical outcome of this is that "[a]nyone who succeeds the covenantor as possessor of the burdened land may be bound, whether or not he happens to hold the covenantor's precise estate." Id. 
Still, as per usual, equity is more relaxed in its requirements than as it is in law. A case in point is the intent element. ${ }^{70}$ While in law wording in the granting instrument must generally contain the word "assigns" or words of similar meaning, equitable servitudes do not require it. ${ }^{71}$ In fact, intent can be determined by the "existence of a general development plan to determine whether the successors were intended to benefit from servitudes, and have inferred lack of intent where no general plan exists." Horizontal privity is also not required, as Cunningham points out, since it is a "self contained equitable interest in land that do[es] not ride along on any other interest or estate." 73

The final element is the notice requirement, which at one time distinguished real covenants from equitable servitudes. In the seminal Tulk case, actual notice was required; that is, before a subsequent purchaser could be burdened or benefited by a covenant, he had to be given literal notice of it. ${ }^{74}$ Today, constructive notice, in which legal notice is sufficient if it simply appears in the public records, is the norm and operates to give proper notice to all relevant parties. ${ }^{75}$ Indeed, the extensive development of constructive notice "has largely made possible the widespread application of equitable restriction theory and has enabled it to eclipse real covenant theory." reciprocal servitudes," in which a developer creates multiple lots and then sells each one to buyers who are both benefited and burdened by uniformly binding covenants (e.g. CC\&Rs) is the model today in residential developments. ${ }^{77}$

Equitable servitudes, like real covenants, are also terminable. Moreover, since equity traditionally eschews the technical and rigid nature of law, more options are available to terminate equitable servitudes than

70. See supra text accompanying note 42.

71. French, supra note 25 , at 1279 ("Use of the words 'assigns' is not required for equitable servitudes, but the parties may be required to designate the parcels of land to be benefited.").

72. Id.

73. Cunningham et Al., supra note 10, at 491.

74. Id. at 492 .

75. See supra note 36.

76. Cunningham et Al., supra note 10, at 492.

77. Id. at 496. It should also be noted that some courts instead apply a third party beneficiary theory, but pre-suppose that the rights are made in contract rather than the more accepted interests in land. See id. at 501; see also supra note 36 . There is a visible trend of "second-generation" cases, in which courts do not "rely[ ] rhetorically upon either of the traditional theories" when deciding issues pertaining to residential subdivisions. Id. at 503 . 
real covenants. ${ }^{78}$ These options include the doctrine of laches,$^{79}$ express or implied waiver by conduct, ${ }^{80}$ waiver by acquiescence, ${ }^{81}$ unclean hands, ${ }^{82}$ estoppel, ${ }^{83}$ and hardship. ${ }^{84}$ Additionally, equitable servitudes may terminate because of the change of neighborhood or conditions defense that was previously discussed. ${ }^{85}$

As the foregoing discussion points out, equitable theory has largely supplanted real covenants. ${ }^{86}$ Accordingly, the manner in which CC\&Rs that govern green building communities terminate includes not only legal considerations, but equitable theory and defense considerations as well. These considerations provide a broad array of methods to attack CC\&Rs, thus requiring the drafter of green building CC\&Rs to draft carefully to avoid potential pitfalls. $^{87}$

\section{E. Architectural Review Boards}

One final issue is the role of architectural review boards. Pursuant to the applicable CC\&Rs, an architectural review board for a given community receives the authority to approve all construction plans according

78. See supra text accompanying notes 52-55 (discussing ways of terminating real covenants).

79. Under laches, if a party seeks to enforce an equitable servitude, such as an action to preserve restrictions that burden another's land, her right to do so is precluded if the defendant, whose land has been burdened, can demonstrate that the plaintiff's delay caused the defendant harm even if the statute of limitations for bringing such an action under law has not run. See Sheppard, supra note 48, at 58; supra text accompanying note 53 .

80. A property owner who benefits from a burden created under an equitable servitude can expressly waive it in an instrument or impliedly waive his rights by conduct. See Sheppard, supra note 48, at 60.

81. Waiver by acquiescence arises when benefiting parties fail to enforce a number of violations in occurring where property is burdened by equitable servitudes. Id.

82. Under the unclean hands defense, a person who is benefiting from an equitable servitude asserts that another is in violation of it while also being in violation. For example, say a party who benefits by living in a CIC in which exterior paint is limited to a number of acceptable colors under the CC\&Rs violates a real covenant by painting his home a prohibited color. This person cannot assert his right to limit his neighbor's violation since he likewise is in violation. See id.

83. In an estoppel, a benefiting party whose words or conduct indicates to parties burdened by the equitable servitude that these parties no longer must adhere to the burden would be estopped from asserting her right to enforce it. See id. at 60-61.

84. Hardship protects a burdened party whose violation of the equitable servitude creates comparatively little harm to those benefiting but if enforced by injunctive relief would create far greater hardship to the burdened party. See id. at 61 .

85. See supra text accompanying notes 52-55.

86. See supra text accompanying notes 70-71.

87. See generally discussion infra Part III. 
to a pre-conceived plan. Likewise, they assume the role of maintaining the integrity of the plan wherein the boards' consent is needed for subsequent changes to the structures enclosed within a CIC. ${ }^{88}$ As with all enumerated restrictions contained in the CC\&Rs, building restrictions run with the land and therefore burden and benefit all the property owners, present and future.

Once a construction plan is produced and incorporated into the $\mathrm{CC} \& \mathrm{Rs},{ }^{89}$ they may be enforced as long as the board's decision is reasonable and arrived at in good faith. ${ }^{90}$ Thus, any new construction or remodeling that incorporates green technologies, particularly those as involved and intricate as LEED certification standards, would need to fit within the parameters of the proposed building plan. Any deviations from the plan would be subject to scrutiny and possible elimination by the board.

\section{GREEN APPLICATIONS TO COVENANTS, CONDITIONS AND RESTRICTIONS}

Given the foregoing discussion of the legal tools available, a residential developer seeking to establish a long-lasting, environmentally sustainable community may use various private tools to regulate land use, rather

88. Stacey Rogers Griffin, Validity and Construction of Restrictive Covenant Requiring Lot Owner To Obtain Approval of Plans for Construction or Renovation, 115 A.L.R. 5th 251, § 21(a)-(b) (2004).

89. See Siegel, supra note 5 and accompanying text.

90. Restatement (Third) of Prop.: Servitudes § 6.13 (2000) (subsec. (d) omitted):

(1) In addition to duties imposed by statute and the governing documents, the association has the following duties to the members of the common-interest community;

(a) to use ordinary care and prudence in managing the property and financial affairs of the community that are subject to its control;

(b) to treat members fairly;

(c) to act reasonably in the exercise of its discretionary powers including rulemaking, enforcement, and design-control powers;

(2) A member challenging an action of the association has the burden of proving a breach of duty by the association ... [and] that the breach has caused, or threatens to cause, injury to the member individually or to the interests of the common-interest community.

See also Palmetto Dunes Resort v. Brown, 336 S.E.2d 15 (S.C. Ct. App. 1985) (discussing a decision upheld on appeal allowing a development's architectural review board to turn down construction plans despite the lack of objective standards for the board to apply as long as the decision bears a reasonable relationship to other buildings in the CIC or to the development's general plan); Mack v. Armstrong, 195 P.3d 1027, 1030 (Wash. Ct. App. 2008) (discussing covenants which require consent from the board before a property owner can begin remodeling or construction must be exercised reasonably and in good faith). 
than allowing government policies to dictate land use outcomes. Two communities on opposite sides of the country provide contrasting approaches for using private enforcement mechanisms to ensure that the construction of green residential structures occurs within their development.

\section{A. Pringle Creek in Salem, Oregon}

Like many other urban infill developments with a green focus, ${ }^{91}$ the Pringle Creek Community is situated on a portion of the land that the state of Oregon once used as the Fairview Training Center for the mentally disabled. ${ }^{92}$ In obtaining the real property in 2002, the developers looked to transform the parcel into an environmentally friendly community within an urban setting where the residents could walk from their homes to most of their daily destinations. ${ }^{93}$

To achieve this goal, the master plan includes four main residential neighborhoods along the ridges of the property's rolling hills, interconnected with paths and sidewalks to allow for pedestrian traffic, as well as access to the village center. ${ }^{94}$ On the northern thirty-two acres, the developers called for the creation of 190 homes called the Pringle Creek Community, where they envisioned one of the nation's largest "Net-Zero" neighborhoods. ${ }^{95}$ Accordingly, the developers explained to reporters their goal: "We wanted to create a national, if not international model for sustainability." 96

\section{Sustainability Approach to Development}

With this lofty ambition in mind for the Pringle Creek Community, the developers needed to invoke some land use procedures to ensure conformity for the construction of homes. As discussed previously, a developer seeking to instill its sustainability beliefs upon a project could use a

91. See generally Laurel Kallenbach \& Kim Wallace, America's Top 10 Green Housing Developments, Natural Home \& Garden (Jan/Feb. 2008), http:/www.naturalhomeandgardennaturalhomeandgarden.com/Inspiration/2008-01-01/Top_10.aspx.

92. Sue Bell, Fairview Training Center, Salem Online History, http://www.salemhistory.net/places/fairview_training_center.htm (last visited Apr. 17, 2012).

93. Dennis Thompson, Shaping the Future, Statesman Journal (Apr. 24, 2005), http://www.pringlecreek.com/news/4_25_05.htm.

94. Id.

95. Id. (explaining that the aim of the "Net-Zero" neighborhood is to utilize solar technology so that the homes create more energy than needed).

96. Michael Rose, Planners May Hand off Fairview:? The Project's Original Developers Will Require That Sustainable Aspect Be Kept, Statesman Journal (Aug, 20, 2005), http://www.pringlecreek.com/news/8_20_05.htm. 
variety of different approaches. ${ }^{97}$ As such, the documents that create the unique private land use requirements of Pringle Creek will bring insight into the approach taken by its developers.

The media that describes Pringle Creek Community mentions that all the buildings are required to attain LEED certification. ${ }^{98}$ To accomplish this requirement, the Pringle Creek master developer turned to using the residential design guidelines administrated by the community's architectural review board as the principle enforcement method.

Within the Pringle Creek CC\&Rs, Article 5 explains how the community will establish and assess proposals for subsequent development. ${ }^{99}$ This section begins by creating the development review committee and the initial requirements for those serving as members. ${ }^{100}$ It also sets forth a mechanism for replacing the members and assigns duties to the committee. ${ }^{101}$

As part of its duties, the committee receives the responsibility to evaluate, determine, and approve each proposal for the construction of a home in the Pringle Creek Community pursuant to the development guidelines it adopts. ${ }^{102}$ Moreover, the article grants powers to the committee to determine whether a submission complies with its approval and sets forth notice and other requirements when a noncompliance situation occurs. ${ }^{103}$ As such, the residential design guidelines serve as the mechanism for compelling a landowner to construct a green building, with the authority conferred to the guidelines by the development review committee via the CC\&Rs.

97. See supra Part II (discussing traditionally used private land use tools under the common law).

98. See, e.g., Zach Mortice, Oregon Housing Starts Below the Lot: Oregon Development Shows That Sustainability Is About a Lot More than Materials and Air Quality, AIA Newsletter (Jan. 2008), http://www.pringlecreek.com/news/1_11_08.htm.

99. Pringle Creek, Pringle Creek Community Declaration § 5 (2005) [hereinafter Pringle Creek Community Declaration].

100. Id. § 5.1.

101. Id. $\$ 5.1-.2$.

102. Id. $\S 5.4, .10$. In the Pringle Creek Community Declarations, the initial Development Review Committee receives the task of drafting and approving the initial Development Guidelines. Id. § 5.4. However, the community declarations make it more difficult to subsequently amend the adopted Development Guidelines because the approval procedure requires a majority of the landowners to vote in favor of any proposal. $I d$. Furthermore, the developer or is successor(s) exempted themselves from the requirement to submit their plans to the Development Review Committee for approval. $I d$. at $\S 5.10$.

103. Id. § 5.5-.6. 
Appendix B of the residential design guidelines provides the requirements to accomplish the developer's sustainable homes objective. ${ }^{104}$ The first section of the appendix explains the community's sustainable development goals and the performance objectives based on different categories it sets forth. ${ }^{105}$ These categories permit a project within the

104. Pringle Creek Community, Residential Design Guidelines app. B at 112 (Sept. 2006) [hereinafter Residential Design Guidelines].

105. Id. Interestingly, the Sustainable Development Goals section provides background information that the design guidelines emanated from the United States Green Building Council's (USGBC) Leadership in Energy and Environmental Design program for Homes(LEED-H). Id. It further explains that the requirements articulated in the guidelines did not completely mirror the LEED-H program since modifications occurred when drafting the document because of the community's unique situation; and a property owner need not obtain USGBC certification to in order to comply with the standards. $I d$. The adopted guidelines reference September 2006 and mention that it utilized the LEED-H program while still in its pilot testing phase. Id. The USGBC pilot tested two versions prior to its January 2008 release of LEED-H Version 2008. See LEED for Homes Rating System infra note 125. The USGBC released Pilot Version 1.72 on September 8, 2005, followed by Pilot Version 1.11 in February 2007. U.S. Green Building Council, LEED for Homes, http:// www.usgbc.org/DisplayPage.aspx?CMSPageID=147\#2008 (last visited Apr. 17, 2012) [hereinafter LEED for Homes Versions]. Based on these dates, Pringle Creek most likely based its guidelines on the earlier Version 1.72. For the foregoing reason, the Green Building Checklist sets forth the following categories with the accompanying goals:

A. Sustainable Sites

1. Site the home to minimize its impact on the existing site features

2. Minimize the disruption of site during construction

3. Orient the home to maximize Natural Resources

4. Utilize native/adaptive landscaping to minimize/eliminate water usage

5. Minimize the use of impervious materials for driveways, patios, walks, etc.

6. Minimize localize heat island effect on the ground by the use of shading vegetation and/or highly reflective paving materials

7. Minimize local heat island effect on roofs

8. Minimize night pollution and maintain dark sky

B. Water Efficiency

1. Minimize use of potable water

C. Energy and Atmosphere

1. Exceed EPA's Energy Star for Homes with third-party Testing

2. Minimize heat loss through envelope

3. Minimize air infiltration with proper detailing and careful construction techniques

4. Maximize use of passive cooling strategies

5. Maximize use of passive heating strategies

6. Maximize efficiency of heating and ventilation systems

7. Maximize efficiency of water heating system

8. Provide onsite electrical generation

9. Maximize efficiency of lighting system

10. Maximize efficiency of appliances 
community to measure a home's performance level against that of the sustainability objectives. ${ }^{106}$ This allows each project owner the ability to select among different alternatives, while accomplishing the same end result. ${ }^{107}$

Moreover, the development review committee recognized that the ultimate goal of Pringle Creek was to advance the community into one that achieves as close to full sustainability as possible. ${ }^{108}$ To accomplish that objective, the sustainable development goals specifically embrace technological improvements, such that the current standard becomes a floor that will continue to harmonize with future technological developments that promote sustainability and will further progress toward the community's aspirations when permissible. ${ }^{109}$

Thus, Pringle Creek follows an indirect approach to achieving its sustainability goals. It uses CC\&Rs that empower the development review committee to adopt residential design guidelines requiring a specific level of environmental sensitivity in the construction of homes, while creating difficult hurdles to make changes until all lots are sold and the community's values change.

\section{Legal Issues with the Approach}

The community's approach provides a great amount of flexibility and latitude for the present, as well as an eye toward the future. It does so by leaving the details open for achieving its objectives to create a malleable system. The developer elected to follow an approach where the appli-

D. Materials and Resources

1. Minimize construction waste

2. Minimize redundant and unnecessary use of materials

3. Maximize use of natural and sustainable products

4. Minimize impact on waste stream

E. Indoor Environmental Quality

1. Minimize impact from dust and debris during construction

2. Minimize leakage of combustion gases into the home

3. Maximize outdoor air ventilation

4. Maximize use of very low-VOC and low-odor materials and finishes

Residential Design Guidelines app. B at 113-116 (Sept. 2006).

106. Pringle Creek Community, Residential Design Guidelines app. B at 112 (Sept. 2006).

107. Id.

108. Id.

109. Id. This language by the Development Review Committee demonstrates its sophistication with the subject matter. The term Green Building, High Performance Building and Sustainable Construction maintain meaningful differences; but often times, the person using these descriptions will use them interchangeably. See Darren A. Prum, Green Buildings, High Performance Buildings, and Sustainable Construction: Does It Really Matter What We Call Them?, 21 Vill. Envtl. L.J. 1, 2 (2010). 
cable CC\&Rs establish a macro policy through the appointment of a development review committee. ${ }^{110}$ This committee in turn establishes and adopts the residential design guidelines where the community's policy is decided. ${ }^{111}$ If the residential design guidelines contain ambiguous language, the development review committee has the ability to interpret the language in line with the overarching goals. ${ }^{112}$ Consequently, Pringle Creek's underlying mechanism for attaining its sustainability goal will allow the community the needed plasticity to adopt a policy that efficiently responds to the evolving nature of the construction industry.

Further, the residential design guidelines do not specify a thirdparty certification, ${ }^{113}$ nor do they use one system as a measuring stick for other programs. The document simply explains the motivation and inspiration behind the requirements and stops short of requiring a third-party verification system for compliance. ${ }^{114}$ As a result, the language, coupled with the community's approach, will enable those charged with enforcing the residential design guidelines, as well as those advocating a position of contention, the ability to come to a mutually beneficial solution, without legal intervention.

Furthermore, the five categories provide enough detail to allow the development review committee sufficient leeway in determining a proper policy to raise incrementally the level of sustainability within the community. While aspirational in nature, the five categories and the accompanying goals provide a broad template whereby the community can elevate or lower the performance standards based on sustainability desires. This avoids any conflict between different versions within a third-party verification program in addition to any variation among the various organizational philosophies in accomplishing the same goal. To this end, the

110. See Pringle Creek Community Declaration, supra note $99 \S 5.1$.

111. Id. $\$ 5.4$.

112. Id. $\$ 5.2$.

113. Beginning in the late nineteenth century followed by a modern resurgence during the 1970s, several organizations noted widespread interest in green buildings. Darren A. Prum, In Third Parties We Trust? The Growing Antitrust Impact of ThirdParty Green Building Certification Systems for State and Local Governments, 27 J. ENVTL. L. \& Litig. 191, 194 (2012). In response to the needs of the industry, several organizations developed proprietary programs to quantify and validate the sustainability features within a building. Id. at 194-95 Among the different third party certification programs, the USGBC offers its own rating system called LEED, the Green Building Institute provides the Green Globes system based upon the United Kingdom's Building Research Establishment's Environmental Assessment Method (BREEAM), and the National Association of Home Builders in conjunction with the International Code Council offers its own system for homes. Id. at 195-199.

114. See supra note 104. 
residential design guidelines become a living document that will change according to the times and technology in order to keep Pringle Creek at the forefront of sustainable communities no matter the program, organization, or philosophy.

Thus, the governing infrastructure and accompanying documents start in a general manner but become more specific with greater flexibility to address emerging issues creates an approach that allows for adaptability and accommodation. This approach avoids unintended consequences over time while providing the framework to attain the community's sustainability goals at the present time and in the future.

\section{B. Kelsey Brook in Freeport, Maine}

The developers of Kelsey Brook in Maine sought to create a residential neighborhood that included environmentally friendly homes, similar to the aspirations of Pringle Creek. The 180-acre Kelsey Brook subdivision fits into a larger development that includes protected conservation areas, natural forests, and agricultural land. ${ }^{115}$ With 80 percent of the larger parcel burdened by two conservation easements, the Kelsey Brook developers along with the town of Freeport, the Freeport Conservation Trust, the state Land for Maine's Future Program, and the federal Farm and Ranch Protection Program forged a master plan for the larger tract. The plan would allow for a select number of homes to be built, while still preserving the natural resources, as well as the existing agricultural and forestry operations on the neighboring farm. ${ }^{116}$ Hence, the Kelsey Brook Development seeks to strike a delicate balance between environmental interests while allowing for a limited number of residential structures.

\section{Sustainability Approach to Development}

In contrast to the Pringle Creek developer's approach, the Kelsey Brook plan chose to follow a different mechanism to bring sustainable features to the newly constructed homes in its neighborhood. The landowners in Kelsey Brook decided to take a direct approach by specifically including green design and construction requirements into the recorded CC\&Rs on the land's title.

In the First Amendment To and Restatement of Declaration of Protective Covenants, Reservations, Restrictions, and Easements of Kelsey

115. Russell DeConti, Building Green At Kelsey Brook: An Informational Guide for Designers, Builders and Homeowners (Feb. 2011) [hereinafter Kelsey BRoOK].

116. Id. 
Brook, the developer sets forth the requirements for building on the real property by subsequent landowners. ${ }^{117}$ Article V Protective Covenants and Restrictions provide the specifics on usage, as well as what and how a subsequent landowner may develop on their lot. This section distributes responsibilities for common areas, in addition to providing maintenance requirements. ${ }^{118}$

In the Design of Dwelling; Approval Process subsection, the declaration explains that any subsequent landowner needs to obtain the original developer's prior approval before constructing a home pursuant to the different restrictions contained in the document. ${ }^{119}$ The language further describes the style, design, and appearance of the building, as well as other aesthetic requirements, such as siding and roofing in conjunction with the look and feel of the exterior. ${ }^{120}$ Moreover, the declaration also addresses building design and siting of the home so that it is "of a character harmonious with the natural rural setting of the land." 121

The declaration imposes unique green building requirements that:

... the design and construction of the dwelling shall be conducted in a manner which is consistent with that recommended by the U.S. Green Building Council's Leadership in Energy and Environmental Design for Homes Program (hereinafter "LEED for Homes Program") or other green building certification program. Said program should set forth green standards for residential dwellings to satisfy (to the extent practicable) similar to those referenced below:

i. Minimize the dwellings adverse impacts;

ii. Utilize heating, cooling, and lighting systems which are energy efficient and use available renewable fuel sources;

ii. Conserve water;

iv. Use environmentally preferred materials that minimize material waste and harmful emissions; and

v. Seek to limit occupant exposure to indoor air pollutants. ${ }^{122}$

This language essentially notifies and requires any subsequent purchaser of land in the Kelsey Brook community that they must construct a

117. Litchfield Property, Inc., First Amendment To and Restatement of Declaration of Protective Covenants, Reservations, Restrictions, and Easements of Kelsey Brook (Feb. 24, 2011) [hereinafter Kelsey Brook CC\&Rs].

118. Id. at Art. V.

119. Id. at Art. V(g).

120. Id.

121. Id.

122. Id. 
green home on their land that will essentially meet the criteria developed by the USGBC LEED-H program. Furthermore, the declaration compels subsequent purchasers of land in Kelsey Brook to provide proof that their development meets the green building threshold through an appropriate third party verification organization. ${ }^{123}$

Hence, Kelsey Brook follows a direct approach to achieving its sustainability goals by giving notice to all subsequent purchasers of land in the community that they will need to construct a home and deliver confirmation that their development meets the USGBC's LEED-H program or equivalent.

\section{Legal Issues with the Approach}

In considering the Kelsey Brook approach, at least three problematic issues may arise.

\section{a. Harmful Unintended Consequences}

The first problem emanates from the language the Kelsey Brook document uses for requiring green building standards within the CC\&Rs. That language creates a unique requirement and obligation for subsequent purchasers within the community that allows for very little flexibility going forward and consequently creates the potential for dangerous unintended consequences. The CC\&Rs establish a homeowners' association in a single document for the community, along with setting very detailed policies, such as those requiring adherence to green building standards. Instead of taking a tiered approach where each successive level provides more details on the community's requirements with the flexibility to make changes along the way, the Kelsey Brook CC\&Rs impose an all-encompassing solution. As a result, the declarant leaves numerous areas of ambiguous language, which will require interpretation by those enforcing the CC\&Rs or possibly the courts, should a dispute occur.

For example, the CC\&Rs specifically mention a particular private entity's third-party verification system as a standard while allowing for equivalents from other organizations. ${ }^{124}$ Such a program may someday cease to operate, merge, or may change its model of operation. This potential problem could leave a subsequent owner in a position where he or she would need to seek an alternate verification organization as permitted by the CC\&Rs. This option creates serious pitfalls since the substitute

123. Kelsey Brook CC\&Rs ("The owner of any lot or building which is subject to the design approval process set forth herein shall pursue a third-party certification that establishes that such owner has met green building guidelines comparable to the LEED for Homes Program guidelines.").

124. Id. 
program may not provide a comparable evaluation to the one originally identified in the CC\&Rs. In response, a subsequent owner may need to seek a legal remedy to remove the requirement from the CC\&Rs, in the event those seeking to enforce the standard refuse to acquiesce when an appropriate organization ceases to exist or a suitable alternative is not available.

\section{b. Lack of Adaptability to Technological Advances}

A second issue involves the declaration, which makes no mention as to what level within the LEED for Homes standard a home must achieve. The USGBC conducted preliminary analysis on two versions of the LEED Program for homes prior to its January 2008 release of LEED-H Version 2008. ${ }^{125}$ The lack of specificity in the Kelsey Brook CC\&Rs leaves the compliance part of the requirement open to interpretation as to how a subsequent owner may satisfy the obligation. Consequently, the guiding principles that seek to bring environmentally friendly homes to Kelsey Brook will allow subsequent owners the opportunity to select the version that fits within their preferred criteria, rather than the level intended by those who drafted the policy.

Considering the future implications, the USGBC will most likely issue newer versions of the program in years to come. But the Kelsey Brook CC\&Rs make no mention of the desire that this requirement or the existing environmental policies to evolve over time. ${ }^{126}$ This ambiguity will further allow subsequent owners to select an outdated version of the program that fits their needs, and it does not provide any environmental benefits over the existing technology at the time of construction. Another potential issue is the possibility of a claim that terminates this requirement of the CC\&Rs under the "change of neighborhood" theory discussed earlier. ${ }^{127}$

A further problem may develop should the declarant decide to remedy the shortcomings of the language included in the CC\&Rs or alter the mechanism for achieving the goal of a more environmentally friendly community part of the subdivided land, an issue may arise out of treating

125. U.S. Green Building Council, LEED for Homes Rating System (Jan. 2008). The USGBC made public Pilot Version 1.72 on September 8, 2005, followed by Pilot Version 1.11 in February 2007. See supra note 105.

126. But see Kelsey Brook CC\&Rs, supra note 117.

127. See supra text accompanying notes 60-64 (discussing the change of neighborhood doctrine in regards to real covenants and equitable servitudes: the doctrine, as discussed, is applied disparately by the various state courts, is the subject of debate among commentators, and would further complicate problems for green developments like Kelsey Brook). 
adjacent parcels differently within the same master plan. Absent a formal release to terminate the requirement, which might financially cost the developer, a subsequent landowner may seek relief from the LEED for Homes requirement again under the "change of neighborhood" doctrine. Since the original CC\&Rs lacked some type of recital or defined sustainability objective, the treatment of two adjacent parcels differently might provide enough substance for a court to nullify the standard or the requirement itself.

\section{c. Difficulties Enforcing Disputes}

Finally, the declarants may face legal action if they fail to enforce the LEED for Homes requirement against all subsequent landowners. This may occur because the previously mentioned issues create too many difficulties that prove unwieldy to implement. In those situations, for example, the doctrine of laches ${ }^{128}$ might allow for aggrieved third-party subsequent landowners a defense against the declarant should the declarant fail to enforce the LEED for Homes requirement placed on the CC\&Rs on all lots in the community. ${ }^{129}$ As a result, the availability of this and other remedies for these landowners creates added pressure toward the declarant, and the need to rectify any ambiguities in the LEED for Homes language as expeditiously as possible.

Therefore, the inclusion of language requiring LEED for Homes directly in the CC\&Rs, despite allowing for comparable programs, serves as a problematic illustration wherein the declarant attempts to impart an environmentally friendly approach to development but uses language and an approach that will create unintended consequences, a lack of flexibility to keep up with technological advances, and possible disputes over compliance.

\section{PROPOSAL FOR FUTURE GREEN HOME COMMUNITIES}

Pringle Creek and Kelsey Brook both seek to accomplish similar goals of adopting green building standards in their respective developments. Importantly, they also provide good reference points for building comparable communities for those who wish to privately regulate green communities in the future. Although the two approaches provide contrasting strategies, they do, at times, employ some of the same tools. Thus, our proposal for future communities seeking the construction of

128. See supra note 79 .

129. See supra text accompanying notes 78-85 (discussing laches and other defenses involving real covenants and equitable servitudes). 
only green homes may wish to consider the following suggestions as the foundation for a strong legally mechanistic approach.

\section{A. The Use of $C C \& R s$}

When considering the role of CC\&Rs as the legal mechanism to create limitations within a given community, the scope and breadth of the CIC itself should provide preliminary guidance. In some situations, landowners prefer a more laissez-faire type of CIC with minimal involvement and intrusion (other than the necessary administrative functions); while in other circumstances, the members of the community prefer more involvement and oversight, similar to the manner in which a local government operates. These two opposing points of view originate out of the language used to draft the CC\&Rs, consequently serving as the foundation for any community seeking to create a private requirement for green home construction.

In examining Pringle Creek and Kelsey Brook, the two communities seem to take the opposite approach to their governance. Pringle Creek appears to have a community with strong involvement by its CIC with additional committees to handle the many supplemental duties required by its more bureaucratic structure. ${ }^{130}$ The CC\&Rs delegate the overall construction and architectural requirements power to a committee to make appropriate project decisions and adopt guidelines. ${ }^{131}$ As such, the green home requirements indirectly originate out of the CC\&Rs, but the document provides the mandate for their existence.

In contrast, Kelsey Brook maintains a more simplified system without the extra committees and duties. ${ }^{132}$ The CC\&Rs create a CIC to oversee, manage, and enforce the rules established in its governing document, while keeping silent about the need for supplemental duties. ${ }^{133}$ The CC\&Rs also impose and detail the green home requirements upon subsequent landowners. ${ }^{134}$ To this end, the green home requirements directly originate out of the CC\&Rs, without a reference to any further guidance other than the LEED-H program.

In consideration of the two communities' respective approaches as groundbreaking models for private green building regulation, a wise master planner should keep the document and accompanying language in a CC\&R declaration more general. As previously discussed, the removing or altering of a CC\&R will provide a master developer great difficulties.

130. See generally Declaration, supra note 99.

131. Id.

132. See generally Kelsey Brook CC\&Rs, supra note 117.

133. Id.

134. Id. 
Should a problem arise in which the CC\&Rs are ambiguous in addressing an issue or result in a change of neighborhood situation, the legal implications for all those involved may become costly. ${ }^{135}$ Accordingly, the CC\&R language should require the creation of an external document that sets policies for subject matters requiring more detail, as well as procedures for updating them when appropriate.

Given the fact that the landscape surrounding green and high-performance buildings, as well as sustainable construction, currently remains highly unsettled and rapidly changing, ${ }^{136}$ the best practice appears to be the creation of a design guidelines type of external document. Such a document provides many advantages at one time. First, it will accommodate both styles, direct and indirect, of CIC governance because the language used to create the document requires the master developer, a special committee, or a general CIC to adopt the external document upon recording the CC\&Rs.

Second, an external document will allow for a more orderly approach to updating and amending the green home requirements. Depending on the master developer's desires, the controlling language in the CC\&Rs can make it easier or more difficult to take subsequent action should the need occur. This advantage fits well with another benefit, which allows the master developer to invoke the same authority it would otherwise be able to maintain as in the CC\&Rs.

Thus, we recommend an indirect approach to the inclusion of a green home construction standard, similar to Pringle Creek's approach for communities looking to further the sustainability cause through the requirement of a design guideline document with all of the necessary details.

\section{B. The Use of Design Guidelines}

In drafting the design guidelines, the master developer needs to consider many aspects of the community. The applicable parts of the Pringle Creek and Kelsey Brook documents provide good illustrations of how to craft the design guidelines by setting forth three important parts: a recital/ aspirational statement, a standard for construction, and some type of flex-

135. See supra Part III(b)(ii), pp. 45-49.

136. See, e.g., Darren A. Prum \& Stephen Del Percio, Green Building Claims: What Theories Will A Plaintiff Pursue, Who Has Exposure, And A Proposal For Risk Mitigation, 37 Real Est. L.J. 243 (2009); Darren A. Prum \& Stephen Del Percio, Green Building Contracts: Considering the Roles of Consequential Damages \& Limitation of Liability Provisions, 23 Loy. Consumer L. Rev. 113 (2010); Darren A. Prum, Green Building Liability: Considering the Applicable Standard of Care and Strategies for Establishing a Different Level by Agreement, 8 Hastings Bus. L.J. 33 (2012). 
ibility to the requirement for unique circumstances. As such, the three sections of the design guidelines need further explanation.

\section{A Recital/Aspirational Statement}

At the beginning of the design guidelines, the aspirational declaration or recitals should supply a broad statement encompassing the values of the community, while setting a direction for the present and future. This statement should serve as a backdrop and provide guidance for the implementation of the agreed-upon standard. It needs to explain the community's goals by setting the green building policy, in addition to providing details on whether the standard sets a floor for future development or desires to progress toward an ideal like complete sustainability.

For example, the Pringle Creek Residential Design Guidelines specifically start the green building checklist with the community's sustainable development goals. ${ }^{137}$ They explain the underlying basis and objectives of the community, in addition to its desires. The document further justifies the basis for the community's standard, while clarifying that the adopted approach for Pringle Creek requires modifications for local conditions as well. ${ }^{138}$ In the end, the conclusion turns toward the community's ultimate goal and explains the standard as a base that will require modification over time and when appropriate. ${ }^{139}$

By including a declaration similar to the one used by Pringle Creek, the design guidelines will serve an important role when the time comes for making policy decisions. This declaration will assist those enforcing the CC\&Rs in resolving issues with controversial construction projects that may or may not meet the required standard. These types of ambiguities will inevitably occur, so the design guidelines will play a crucial role in guiding whoever needs to settle a dispute in which a lack of specificity in the green building standard exists. Furthermore, the declaration should provide guidance on the future direction of the community and when to update or change the standard over the long term.

Accordingly, the aspirational statement or recital may not seem important in the beginning of the drafting process, but it will assume a crucial role when the implementation and operational phases occur.

\section{A Standard for Construction}

Following the aspirational statement or recital, the design guidelines should create a distinct standard for the community. When determining

137. See Residential Design Guidelines, supra note 104.

138. Id.

139. Id. 
an appropriate standard, the community may look to develop its own or use one created by a third-party organization. ${ }^{140}$ In choosing a standard, some third-party organizations like the USGBC and the National Association of Home Builders offer green building assessment tools that will offer a community with some level of measurement; at other times a state or local government maintains its own program, like the Austin Energy Green Building or the state of New York. ${ }^{141}$ Should the community decide to select an established program, it will also need to resolve whether to require certification by the third-party organization or to allow a property owner to demonstrate compliance by other means.

In Pringle Creek, the LEED-H pilot program served as the basis for the standard adopted by the community, but it chose to develop its own approach that did not make certification compulsory. ${ }^{142}$ The Pringle Creek standard sets forth categories and a framework for the community, while allowing each home developer the ability to select its own method to meet the various requirements. ${ }^{143}$

Following a different approach, Kelsey Brook selected the LEED-H standard as its third-party verification program, but it will allow another organization's standard, so long as it adheres to the enumerated categories listed in the CC\&R declaration. ${ }^{144}$ Beyond choosing a third-party verification program, Kelsey Brook took the added step of requiring certification from the program that determines compliance with the community's green building standard. ${ }^{145}$

Each of the communities' methods will have positives and negatives. A given community will need to weigh each approach for applicability to its own unique circumstances and those that closely relate to the aspirational statement previously discussed. ${ }^{146}$ The national programs provide

140. See Darren A. Prum ET AL., In Third Parties We Trust? The Growing Antitrust Impact of Third-Party Green Building Certification Systems for State and Local Governments, 27 J. EnvTl. L. \& Litig. 191 (2012); Darren A. Prum, Creating State Incentives for Commercial Green Buildings: Did the Nevada Experience Set an Example or Alter the Approach of Other Jurisdictions?, 34 WM. \& MARy EnvTL. L. \& PoL'y Rev. 171 (2009).

141. See Darren A. Prum ET AL., In Third Parties We Trust? The Growing Antitrust Impact of Third-Party Green Building Certification Systems for State and Local Governments, 27 J. EnvtL. L. \& Litig. 191 (2012); Darren A. Prum, Creating State Incentives for Commercial Green Buildings: Did the Nevada Experience Set an Example or Alter the Approach of Other Jurisdictions?, 34 WM. \& MARY ENVTL. L. \& POL'y ReV. 171 (2009).

142. See Residential Design Guidelines, supra note 104.

143. Id.

144. See generally Kelsey Brook CC\&Rs, supra note 117.

145. Id.

146. See supra text accompanying notes 130-132. 
an established standard, but their design and focus must accommodate the diversity of locations across the country. This may not fit a given community as well as some of the government programs, which may have more of a local focus.

On the other end of the spectrum, a propriety program can provide a tailor-made solution. Still, a community must maintain the expertise to develop such a standard without creating a program in name only. It also requires a knowledgeable staff that keeps abreast of the latest developments in many areas, like technology and materials. Unfortunately, this kind of expertise may cost more than a community can afford.

Thus, the community will need to determine the proper level of sustainability to impose upon subsequent landowners by selecting a standard that fits within the aspirational statement while providing a particular degree of compliance towards the green building goals.

\section{A Built-In Flexibility to the Standard}

Finally, the design guidelines need to allow the development to address a variety of situations that may arise over time. Without this flexibility, there exists the risk of legal action when disputes arise. Once the community establishes a standard, the reality of implementing the criteria will most likely encounter various requests and interpretations as subsequent landowners seek to add their own unique desires. These variances and interpretations may originate from many different sources, such as technological progression, the termination of a green building program relied upon by the community, or the obsolescence of a particular requirement.

To avoid these types of issues, Pringle Creek serves as a fitting model. It took several affirmative steps to ensure flexibility and minimize the possibility of a legal dispute. For example, the community created its own standard predicated on the pilot version of the LEED-H program. ${ }^{147}$ By taking this action, Pringle Creek alleviated many of the issues associated with a third party's program and possible updates.

Committees to oversee the implementation and execution of the green building standards are also important. They can be used to involve the other residents in the community, as well as provide an additional level of oversight and participation for resolving issues prior to legal action. Since a challenge is inevitable given the complexity of a green construction project, the use of an oversight committee allows the community more opportunities to interject common sense and compromise.

147. See Residential Design Guidelines, supra note 104. 
Moreover, the aspirational statement that guides the community to raise the standards when necessary provides a direction for interpreting any unintended issues that may evolve. ${ }^{148}$ This authority to periodically review the approach taken by the community and make necessary corrections has given Pringle Creek a more flexible method to resolve future differences. Consequently, the Pringle Creek approach is highly supple, with both the structural oversight and the aspirational and controlling language for implementing the sustainable community objectives.

Conversely, Kelsey Brook chose to adopt the LEED-H standard or a similar one provided it compares favorably with several categories identified in the CC\&Rs. ${ }^{149}$ As previously discussed, this approach created several ambiguities that allows for multiple interpretations of which version of LEED-H would fulfill the requirement. ${ }^{150}$ This gap could lead to a "change of neighborhood" claim in the future should separate lots receive different treatment based on the adopted standard and would leave a subsequent landowner with no option other than the courts to obtain relief.

Furthermore, the decision to stipulate a LEED-H program does not compel a progressive pattern onto later home construction projects to adhere to new standards as the green building standard gets raised due to the evolution of current sustainability practices. Absent further guidance from Kelsey Brook's CC\&Rs, nobody knows which direction the community should take as a next step; yet the restriction remains on the land to meet the LEED-H or its equivalent. As a result, the Kelsey Brook approach demonstrates the need to consider the present and future implications of the controlling language such that the community can update and amend any issues while determining a basis for its interpretation when questions arise.

To deal with these needs, we propose that the language used to adopt the green building standard must avoid ambiguous meanings through careful deliberation. An ambiguity could unintentionally occur if the design guidelines stipulate to a particular program associated with a third-party verification organization and allows for multiple interpretations through vague references. The document must provide precise definitions for compliance upon execution, while allowing for updates and amendments over time. It needs to take into account the aspirational statement in case the ambiguity needs future clarification.

148. Id.

149. See generally Kelsey Brook CC\&Rs, supra note 117.

150. See discussion supra Part III(b)(ii), pp. 45-49. 
In addition, the community must provide managerial and interpretive oversight to the design guidelines. While each community will determine the level and extent that a CIC shall govern, subsequent landowners as well as the community as a whole need a responsible party with the ability to interpret, amend, and update the design guidelines. This authority may lie with an architectural review committee or the CIC as a whole depending on how the community chooses to operate. However, this responsible party's functions with regard to the green building objectives and implementation serve a crucial role to defuse challenges that will inevitably be leveled against the design guidelines. Hence, the design guidelines need to provide a degree of flexibility so that the community will continue to follow its aspirational statement and progress toward its ultimate goal without the need for legal action to find a solution.

Therefore, we recommend that a master developer seeking to create a private sustainable community should follow a two-part approach. First, the CC\&Rs should contain language that delegates the appropriate standard to an external document. Such a document will advance the second part by explaining the design guidelines. In this way, subsequent landowners can understand what the green building objectives and aspirations are through a categorical yet still-evolving standard that maintains a degree of flexibility. By employing this approach, a responsible party will be empowered to implement, amend, and update when necessary.

\section{CONCLUSION}

For centuries, the English and American common law have both fostered the notion that property owners should be free to plan and build a living environment that best serves their communal interests. This notion is now expanding into sustainable green communities which seeks to promote a more environmentally friendly and sustainable lifestyle. This trend becomes ever more vital in a world besieged by threats of global climate change and urgent calls for lessening our carbon imprint and preserving water as well as finite resources.

Still, a number of potential legal pitfalls can arise when creating private sustainable communities. The master developer must be designed with great care. Additional green objectives may cause unintended results due to the uncertainty and fluidity of the subject matter.

The pioneering communities of Pringle Creek and Kelsey Brook provide excellent case studies of a diverse structural style for oversight, strategies for adopting a standard, and approaches for developing solid legal language. They demonstrate that the master developers of Pringle Creek and Kelsey Brook must maintain a plethora of legal mechanisms to 
accomplish their goals. These goals must reveal the reality of living in a private sustainable community, but they must assure that the legal hurdles are not insurmountable. As such, our macro-level proposal draws upon Pringle Creek and Kelsey Brook's governing documents to offer insight and reflection to master developers seeking to create their own private sustainable communities.

With this in mind, we submit an integrated approach that accomplishes several goals. The primary task is to craft an entry-level green home community to advance the larger goal of complete sustainability. This is accomplished where the governing documents are enforced against subsequent land purchasers and thus provide for a well-conceived standard with flexibility to adjust to the present and future challenges inevitably facing such a development. 